\title{
Physiological and Biochemical Responses of Invasive Species Cenchrus pauciflorus Benth to Drought Stress
}

\author{
Liye Zhou ${ }^{1}$, Xun Tian ${ }^{2}$, Beimi Cui ${ }^{3, *}$ and Adil Hussain ${ }^{4, *}$ (1) \\ 1 College of Agronomy, Inner Mongolia University for Nationalities, Tongliao 028000, China; toni2002@126.com \\ 2 College Life and Food Science, Inner Mongolia University for Nationalities, Tongliao 028000, China; \\ tianxun@imun.edu.cn \\ 3 Institute of Molecular Plant Sciences, School of Biological Sciences, University of Edinburgh, \\ Edinburgh EH9 3BF, UK \\ 4 Department of Agriculture, Abdul Wali Khan University Mardan, Khyber Pakhtunkhwa 23200, Pakistan \\ * Correspondence: beimi20051@163.com (B.C.); adilhussain@awkum.edu.pk (A.H.)
}

Citation: Zhou, L.; Tian, X.; Cui, B.; Hussain, A. Physiological and Biochemical Responses of Invasive Species Cenchrus pauciflorus Benth to Drought Stress. Sustainability 2021, 13, 5976. https://doi.org/10.3390/ su13115976

Academic Editors: Rahul Datta, Subhan Danish and Shah Fahad

Received: 29 March 2021

Accepted: 18 May 2021

Published: 26 May 2021

Publisher's Note: MDPI stays neutral with regard to jurisdictional claims in published maps and institutional affiliations.

Copyright: (c) 2021 by the authors. Licensee MDPI, Basel, Switzerland. This article is an open access article distributed under the terms and conditions of the Creative Commons Attribution (CC BY) license (https:/ / creativecommons.org/licenses/by/ $4.0 /)$.

\begin{abstract}
The invasive plant Cenchrus pauciflorus Benth exhibits strong adaptability to stress, especially drought. When newly introduced certain plant species can become invasive and quickly spread in an area due to lack of competition, potentially disturbing the ecological balance and species diversity. C. pauciflorus has been known to cause huge economic losses to agriculture and animal husbandry. Thus, understanding the physiological responses of $C$. pauciflorus to drought stress could help explore the role of $C$. pauciflorus in population expansion in sandy land environments. In this study, we evaluated the response of C. pauciflorus to induced low, moderate, and severe drought stress conditions. Results showed a linear reduction in the fresh weight (FW), dry weight (DW), and relative water content (RWC) of the aboveground parts of $C$. pauciflorus following drought stress as compared to the control plants (no drought stress). Chemical analyses showed that the drought treatments significantly induced the production of proline, soluble proteins, soluble sugars, MDA, and free amino acids as compared to the control treatment (no drought stress). On the other hand, the starch content was significantly reduced in drought-treated plants. This was also accompanied by a significant linear increase in the antioxidant enzyme activities (SOD, POD, and CAT) in plants subjected to drought stress. On the basis of physiological and biochemical analyses, we propose that C. pauciflorus has evolved to survive harsh drought stress conditions of the desert via sophisticated biochemical adjustment and antioxidant reprograming that allows protection against damage caused by drought stress.
\end{abstract}

Keywords: field sandbur; Cenchrus pauciflorus; invasive species; drought stress

\section{Introduction}

The biological invasion of certain species has seriously threatened biodiversity, ecosystem, resource availability, and sustainable economic development worldwide. Horqin sandy land, located in the southeast of the semi-arid agro-pastoral transitional zone, is an area extremely sensitive to global change and one of the areas most seriously affected by desertification [1]. Since it was first recorded in 1983, Cenchrus pauciflorus Benth, an annual herb belonging to the genus Tribulus of Gramineae, has become one of the most invasive weeds in Horqin sandy land. This invasion has seriously affected the normal utilization of grassland resources and community composition, aggravated soil desertification, and further deteriorated the already fragile ecosystem [2]. Once the seedlings of C. pauciflorus survive, they spread rapidly, forming a unique drought response mechanism [3]. C. pauciflorus is a globally widespread invasive plant and is capable of adapting to a variety of environmental conditions [4,5]. Historically, it has been known by several names such as C. echinatus, C. incertus, C. parviceps, C. spinifex, coastal sandbur, grass bur, and others [6]. The species is native to South America, Africa, Asia, and throughout the other tropical 
and sub-tropical areas, and is especially adapted to dry and sandy soils, being registered as one of the world's worst weeds [7]. These attributes indicate that C. pauciflorus has the capability to quickly become invasive once introduced in a new area. Drought stress is one of the most important abiotic limiting factors in crop productivity throughout the world. It occurs due to a shortage of water and can have several causes, such as low or no rainfall or irrigation, unsuitable soil structure and soil texture, salinity, temperatures being too high or low, and others. It is a multi-dimensional stress and its effects range from morphological to molecular levels and are phenologically visible at all stages of plant growth. For example, the first effect of drought stress is impaired germination [8,9]. Drought stress has the ability to severely reduce germination and growth at the seedling stage [10]. Cell division, enlargement, and differentiation drive overall plant growth. However, these processes are drought-sensitive as they are affected by reductions in turgor pressure. Continuous drought stress reduces plant growth and development leading to a significant reduction in flower production, grain fill, and number. More specifically, the plant-water relations in which the negative impact of drought stress is more prominent include relative water content, leaf water potential, rate of transpiration, stomatal resistance, canopy temperature, and leaf temperature. On the other hand, drought stress also limits nutrient uptake from the root zone, affecting the nutrient concentration in plant tissues due to the uncoupling of nutrient loading and unloading in the root zone (source) and above-ground plant parts (sink) and reduced transpiration flow, though different plant species and cultivar may vary in their response to such phenomena under varying degrees of water deficit. In general, at the tissue level, low moisture stress results in higher $\mathrm{N}$ and lower $\mathrm{P}$ concentrations [11].

Perturbations in nutrient uptake and transportation affect the process of photosynthesis due to defective leaf expansion, premature leaf senescence, abnormal photosynthetic machinery, and other factors such as the disturbance of the Calvin cycle [12-14]. Subsequent imbalances in the cellular redox homeostasis and antioxidant defense mechanisms also negatively affect the process of photosynthesis, however, they do contribute to a plant's tolerance mechanism $[13,15]$ due to the direct toxic effects of various reactive oxygen species (ROS) on different proteins and lipids. The production of various ROS is linear with the severity of drought stress.

Furthermore, in order to deal with such negative effects of drought stress, plants need a compensatory increase in the efficiency of respiration. Plant growth and development and environmental conditions affect the rate and efficiency of respiration [16]. Abiotic stress, especially drought stress, results in the production of reactive oxygen species (ROS) at the cellular level. ROS can prove to be toxic for the plants per se, as they may cause oxidative damage by reacting with lipids, proteins, and nucleic acid $[17,18]$. ROS production is usually linear with the severity of drought stress [19]. Cellular organelles such as chloroplasts, mitochondria, and peroxisomes are the first sources as well as ROS targets during drought stress. Prolonged drought stress may cause non-recoverable effects on plant life.

Water stress induces the accumulation of abscisic acid [20], a phytohormone that regulates plant sensitivity to drought and salt stress [21-23]. A shortage of water also reduces the rate of photosynthesis. Certain plant species are naturally more tolerant to water shortages than others. Though the mechanisms underpinning drought stress tolerance are complex and involve intricate interconnected pathways, these enable the plants to regulate drought stress responses via stomatal conductance, carotenoid degradation, the production of secondary metabolites such as anthocyanin, and the streamlining of ROS production and metabolism. Desert xerophytes are specifically adapted to extreme heat and drought conditions as they have special means of absorbing, storing, and conserving water in their bodies [24]. They usually have no leaves at all, which reduces water loss through transpiration. Phreatophytes are plants that grow in semi-arid conditions and have extremely long roots that enable them to absorb moisture at or near the underground water table [25]. Hence, understanding the mechanisms of drought stress tolerance in these 
species can help transfer drought tolerance traits to crop species via classical breeding or genetic engineering.

C. pauciflorus is found in many parts of the world, especially in sandy or gravelly terrain such as some deserts. C. pauciflorus is a poor competitor, however it easily colonizes well in sandy areas indicating a natural drought resistance in this plant species [4]. Thus, in order to understand the physiological responses of C. pauciflorus to drought stress in Horqin sandy land, the seedling of C. pauciflorus was taken as the research object in this study, the potted water control (from low, moderate, to severe treatment) methods were used to simulate drought conditions, and the potential habitats for adaptation of C. pauciflorus were further clarified from the changes of physiological characteristics, so as to provide scientific evidence for use in the effective control of C. pauciflorus.

\section{Materials and Methods}

\subsection{Plant Material and Growth Conditions}

C. pauciflorus seeds (mature burs) were collected in October 2019 from Sihetun sites in Horqin sandy land $\left(43^{\circ} 40^{\prime} \mathrm{N}, 122^{\circ} 04^{\prime} \mathrm{E}\right)$. The soil is comprised of loose sand ( $\left.\mathrm{pH}=7.8\right)$, and land degradation in this region has spread rapidly. The average annual temperature ranges from $-12.1{ }^{\circ} \mathrm{C}$ in January to $23.3^{\circ} \mathrm{C}$ in July. The mean annual precipitation is $293 \mathrm{~mm}$ with more than 70\% of this falling during the growing season (from May to September). The average mean annual wind speed is $3.8 \mathrm{~m} \mathrm{~s}^{-1}$, with the windy season generally occurring between March and May. The various chemical characteristics of the soil in the experimental area have been described in Table 1 below.

Table 1. Different drought stress treatments of C. pauciflorus.

\begin{tabular}{ccccccc}
\hline Items & $\begin{array}{c}\text { Organic } \\
\text { Matter }\end{array}$ & $\begin{array}{c}\text { Total } \\
\text { Nitrogen }\end{array}$ & $\begin{array}{c}\text { Available } \\
\text { Phosphorus }\end{array}$ & $\begin{array}{c}\text { Available } \\
\text { Potassium }\end{array}$ & $\begin{array}{c}\text { Alkali } \\
\text { Hydrolyzed }\end{array}$ & pH \\
\hline Content & $4.4(\mathrm{~g} / \mathrm{kg})$ & $0.5(\mathrm{~g} / \mathrm{kg})$ & $7.7(\mathrm{mg} / \mathrm{kg})$ & $155.5(\mathrm{mg} / \mathrm{kg})$ & $53.5(\mathrm{mg} / \mathrm{kg})$ & 7.8 \\
\hline
\end{tabular}

C. pauciflorus seeds were soaked in water for $24 \mathrm{~h}$ before sowing in pots containing a 1:1 ratio of soil to vermiculite. Plants were grown in $9.5 \mathrm{~cm} \times 9.5 \mathrm{~cm}$ pots. A density of about 35 uniform sized plants per pot was maintained and regularly watered. Watering was stopped when the plants reached the 4 or 5-leaf stage, so that the soil water content was maintained at: $85-90 \%$ of the soil water holding capacity (designated as the control treatment), $65-70 \%$ of the soil water holding capacity (mild drought), $45-50 \%$ of the soil water holding capacity (medium or moderate drought), and $25-30 \%$ of the soil water holding capacity (severe drought), as shown in Table 2. All the soil water contents were maintained as measured by the pots' weight. Each treatment was replicated three times. Treatments were continued for five days after which samples were collected for measurements of fresh weight, water content, and other further analyses.

Table 2. Different drought stress treatments of C. pauciflorus.

\begin{tabular}{ccc}
\hline Treatment & Stress Level & Soil Water Content \\
\hline Control & Normal water supply & $85-90 \%$ of field water holding capacity \\
Mild Drought & Mild drought stress & $65-70 \%$ of field water holding capacity \\
Moderate Drought & Moderate drought stress & $45-50 \%$ of field water holding capacity \\
Severe Drought & Severe drought stress & $25-30 \%$ of field water holding capacity \\
\hline
\end{tabular}

\subsection{Fresh Weight and Water Content Measurements}

The above ground portions of the plants were harvested and weighed immediately to measure the fresh weight $(F W)$. After measuring the fresh weight, the aboveground parts of the plant were dried in an oven at $75{ }^{\circ} \mathrm{C}$ for two days, and the dry weights (DWs) were measured. The water content (\%) was measured as described by Cuizhi et al. [26], as below. 


$$
\text { Water Content }(\%)=\frac{F W-D W}{F W} \times 100
$$

where $F W$ is fresh weight and $D W$ is dry weight.

\subsection{Antioxidant Enzyme Extraction and Quantification}

For the enzyme assay, $0.2 \mathrm{~g}$ of leaf tissue were ground in a Tissue Lyser II (Qiagen) with a $2 \mathrm{~mL}$ extraction buffer containing $50 \mathrm{mM}$ potassium phosphate buffer ( $\mathrm{pH} 7.6)$ and $0.1 \mathrm{mM}$ EDTA-2Na. The homogenate was centrifuged at $15,000 \times \mathrm{g}$ for $15 \mathrm{~min}$ at $4{ }^{\circ} \mathrm{C}$ and the supernatant was collected to perform POD, CAT, and SOD activity assays as described by Cakmak, et al. [27].

\subsection{Physiological Index Measurements}

Tissue proline, malondialdehyde (MDA), total soluble sugars (TSSs), and soluble protein content were measured in plants subjected to the above different treatments as described by Baghizadeh, et al. [28]. Furthermore, free amino acid content and soluble sucrose were measured according to method described by Aragão, et al. [29]. Starch analysis was performed according to Chow and Landhausser [30] and root vigor measurements were carried out as described by Liu, et al. [31].

\subsection{Integrated Assessment of Anti-Drought Ability via Membership Functional Analysis}

The anti-drought ability of $C$. pauciflorus was assessed through use of the subordination function method in fuzzy mathematics, outlined in the following equation.

$$
\begin{gathered}
x(u)=\frac{\left(x-x_{\text {min }}\right)}{\left(x_{\max }-x_{\min }\right)} \\
x(u)=1-\frac{\left(x-x_{\text {min }}\right)}{\left(x_{\max }-x_{\min }\right)}
\end{gathered}
$$

where $x=$ the measured value of any parameter in C. pauciflorus.

$x_{\max }$ and $x_{\min }=$ the maximum and minimum of the measured values of the parameters, respectively. If a parameter in C. pauciflorus had a positive correlation with that in forage, then Equation (1) was applied, if not, Equation (2) was applied. The values of subordination were calculated and averaged. A larger average value represented a stronger drought tolerance and vice versa. All data analyses were performed using ANOVA and a significance test at $p=0.05$.

\subsection{Statistical Analysis}

All the experiments were performed in triplicate. Data analyses were performed using Microsoft Excel and SPSS17.5. Analysis of variance (ANOVA) was performed at $p \leq 0.05$ and the means with significant differences were separated using Duncan's multiple range test (DMRT).

\section{Results}

\subsection{Effect of Drought Stress on C. pauciflorus}

Water deficit is one of the most important limiting factors in plant growth. The different water deficit regimes had a significant effect on the growth and development of C. pauciflorus (Figure 1A). This was reflected by the negative effects of the treatments on different agronomic parameters of the plants. A significant reduction in fresh weight was observed in all the plants grown under different water limiting conditions, with the highest reduction in fresh weight recorded in the plants grown under severe drought conditions, followed by those grown under moderate and mild drought stress (Figure 1B). A similar pattern showing a significant and linear reduction in dry weight (Figure 1C) 
and water content (Figure 1D) was observed in C. pauciflorus plants following drought stress treatments.

A
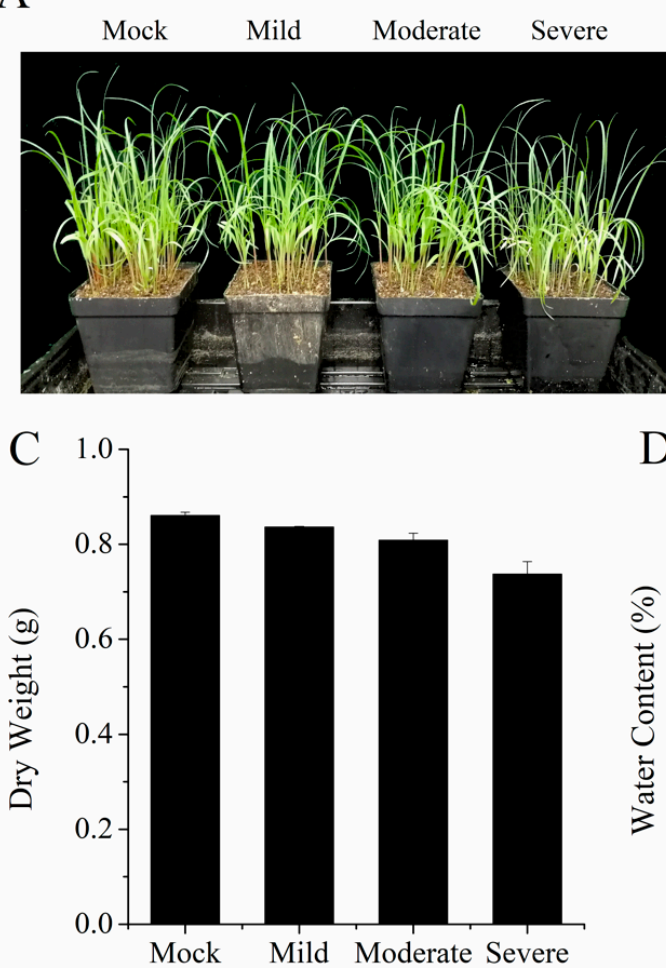

B

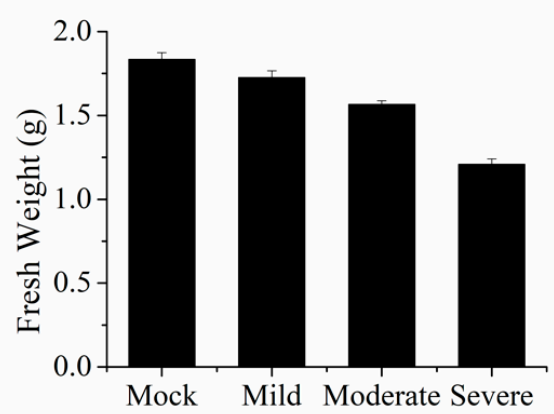

D 1.2

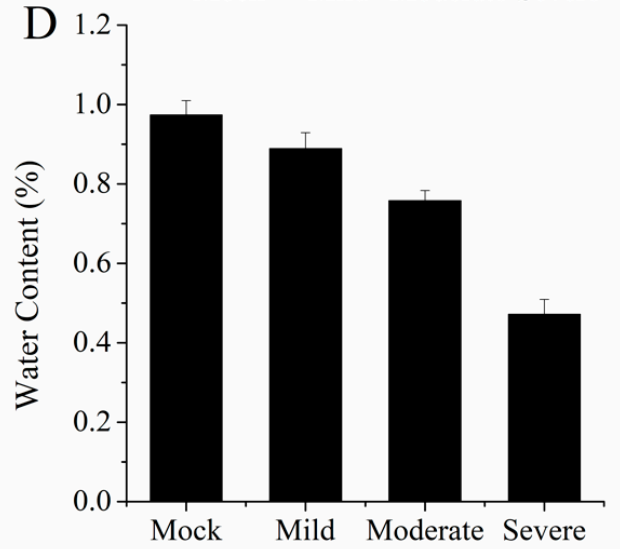

Figure 1. Effect of drought stress on C. pauciflorus. Morphological effects of mild, moderate, and severe drought stress treatments on the C. pauciflorus plants (A). Measurements of plant fresh weight (B), dry weight (C), and water content (D). Bars indicate means of at least three replicates. Error bars indicate standard error.

\subsection{Effects of Drought on Proline Content in C. pauciflorus}

Proline plays a protective role during water deficit regimes, protecting the cells from membrane damage and protein denaturation. Thus, we examined the proline content of plants following drought stress treatment. The results showed that drought stress resulted in an almost linear increase in the average proline content of the C. pauciflorus plants (Figure 2A), though there was no significant differences between the proline contents of the control plants and those subjected to mild water shortage. This indicates that proline acts to protect plants primarily at higher and/or longer periods of drought stress. Besides, it also indicates that higher concentrations of proline at moderate to severe drought stress conditions are responsible for the high drought tolerance of C. pauciflorus.

\subsection{Effect of Drought on Antioxidant Enzyme Activity in C. pauciflorus}

The activation of the cellular antioxidant machinery is a common phenomenon following drought stress, characterized by the production of different antioxidant enzymes such as peroxidase (POD), catalase (CAT), and superoxide dismutase (SOD). Therefore, we measured the activity of these antioxidant enzymes in C. pauciflorus drought stress-treated plants. Interestingly, no significant difference in POD activity between the control plants and mild drought stress-treated plants was observed. However, a significant increase of about $180 \%$ and $210 \%$ in the POD activity was observed in plants grown under moderate and severe drought stress conditions, respectively, in comparison to the control-treated plants (Figure 2B). Changes in the catalase activity of the plants following drought stress treatment was more robust and a significant increase in the overall catalase activity was observed in response to severe, medium, as well as mild drought stress compared to the 
control treatment. More specifically, though statistically similar levels of catalase activity were recorded following mild and moderate water deficit conditions, severe drought stress caused a highly significant increase in catalase activity (Figure 2C) indicating a drastic increase in the accumulation of various ROS in response to severe water shortages. As expected, we recorded an almost similar increase in the overall superoxide dismutase (SOD) activity in C. pauciflorus leaves following the various drought stress treatments (Figure 2D).

A

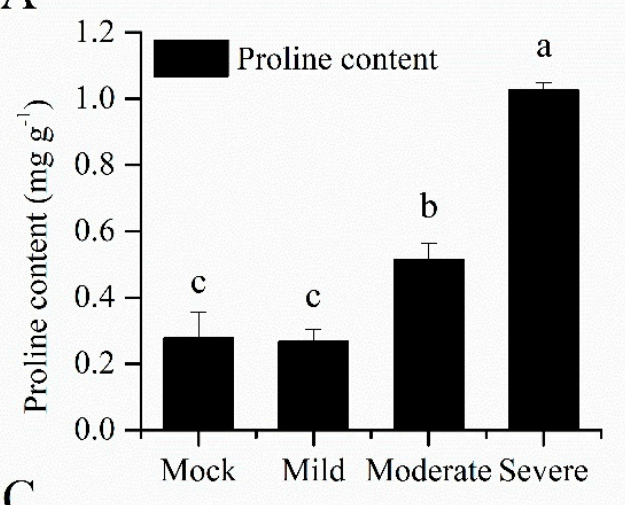

C

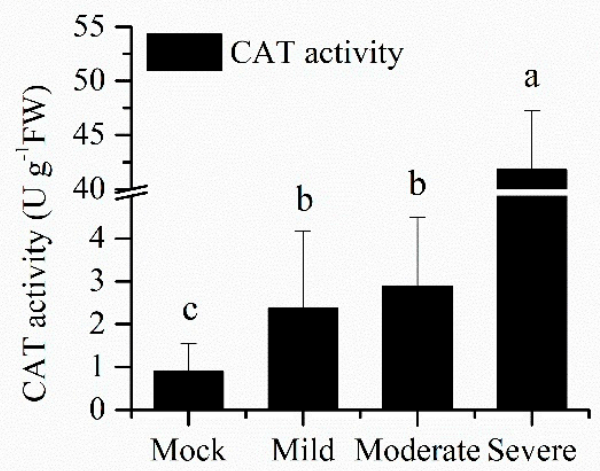

B
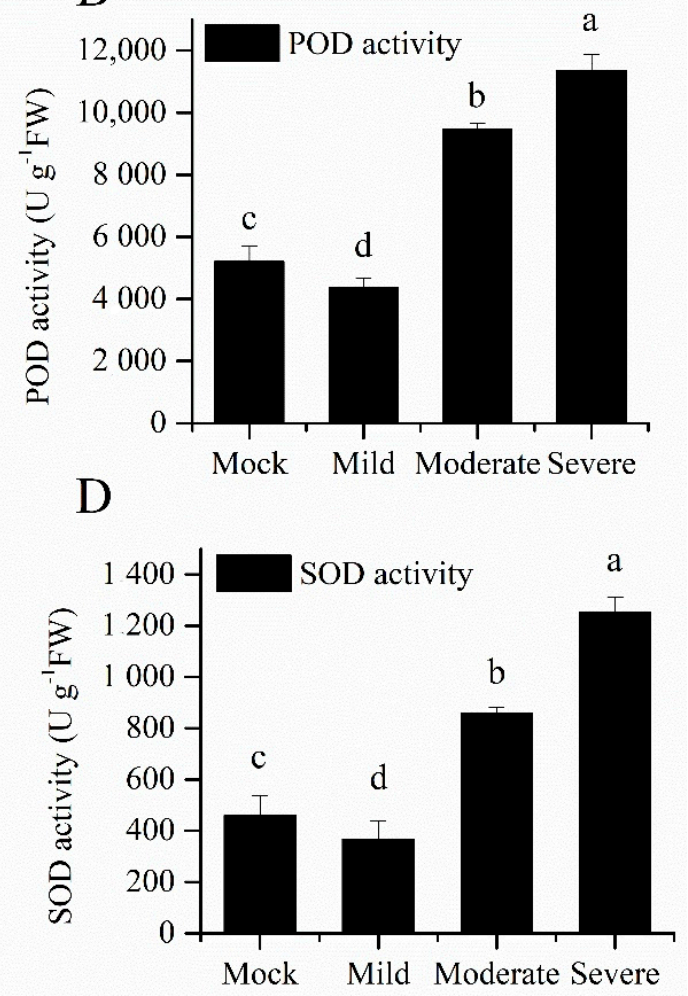

Figure 2. Biochemical effects of water deficit on C. pauciflorus. The response of C. pauciflorus to different levels of drought stress treatments was determined by measuring various biochemical parameters such as the proline content (A), and various drought-responsive enzymatic activities such as peroxidase (B), catalase (C), and superoxide dismutase (D) activity. Bars indicate means of at least three replicates. Bars with different letters indicate a significant difference between the two means at $p \leq 0.05$. Error bars indicate standard error (SE). Analysis of variance (ANOVA) was performed at $p \leq 0.05$ and the means with significant differences were separated using Duncan's multiple range test (DMRT).

\subsection{Effects of Drought on Soluble Sugars and the Soluble Protein Content of C. pauciflorus}

Similar to proline, soluble sugars also accumulate to protect membranes from damage and stabilize the structure and activities of enzymes and other biomolecules. The accumulation of soluble sugars in C. pauciflorus plants grown under different water deficit regimes showed the same linear pattern. For example, the soluble sugars increased to $5.39 \mathrm{mg} \cdot \mathrm{g}^{-1}$ FW in plants subjected to severe drought stress treatment and $3.19 \mathrm{mg} \cdot \mathrm{g}^{-1} \mathrm{FW}$ in those grown at mild drought stress conditions, respectively, as compared to only $0.93 \mathrm{mg} \cdot \mathrm{g}^{-1}$ FW in the control-treated plants (Figure 3A). This indicates that the soluble sugars content in C. pauciflorus significantly increased as a result of the higher drought stress treatments.

Interestingly, the total soluble protein content of $C$. pauciflorus following drought stress treatments showed a different pattern. As shown in Figure 3B, the soluble protein decreased significantly by up to $50 \%$ and $39 \%$ in the plants grown under mild and moderate water deficit conditions, respectively. However, plants grown under conditions representing severe drought stress accumulated a significantly higher quantity of soluble protein of 
up to $0.66 \mathrm{mg} \cdot \mathrm{g}^{-1} \mathrm{FW}$ as compared to $0.42 \mathrm{mg} \cdot \mathrm{g}^{-1} \mathrm{FW}$ soluble protein in the controltreated plants.
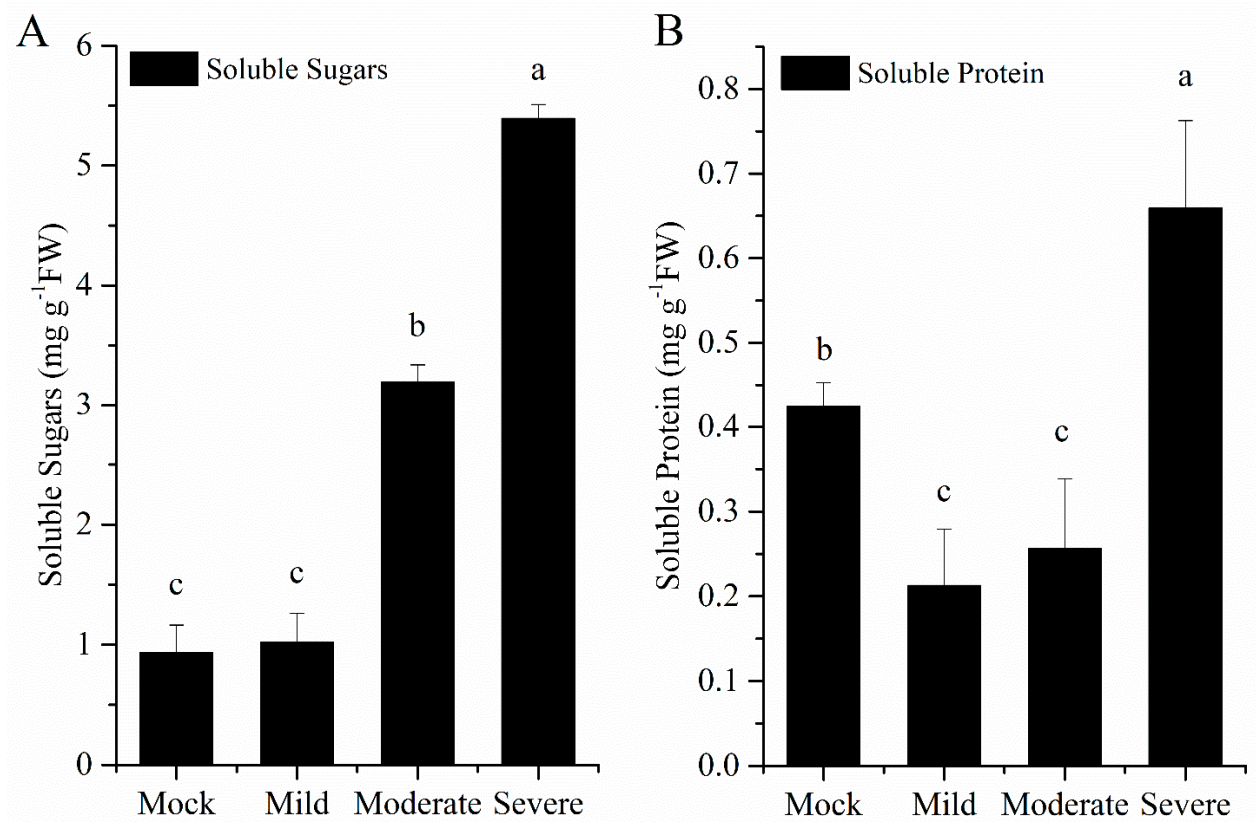

Figure 3. Effect of water deficit conditions on soluble sugars (A) and soluble protein (B) in C. pauciflorus. Bars indicate means of at least three replicates. Bars with different letters indicate a significant differences between the two means at $p \leq 0.05$. Error bars indicate standard error (SE). Analysis of variance (ANOVA) was performed at $p \leq 0.05$ and the means with significant differences were separated using Duncan's multiple range test (DMRT).

\subsection{Effect of Drought on Malondialdehyde, Starch, Free Amino Acids, and Root Vigor of C. pauciflorus}

Malondialdehyde (MDA) is a naturally occurring oxidative stress marker. It is produced as the result of the lipid peroxidation of polyunsaturated fats by various reactive oxygen species. Earlier measurements following water deficit treatments indicated a significant increase in the accumulation of ROS in C. pauciflorus plants. Thus, we measured the MDA content to determine the extent of the oxidative damage caused by ROS in terms of lipid peroxidation. As expected, MDA content increased significantly following the drought stress treatments relative to the control, with the highest increase recorded in the plants grown under severe drought stress conditions (Figure 4A). Similarly, we recorded a linear but inverse relationship between the severity of drought stress and the starch content of the C. pauciflorus plants, as the highest starch content was recorded in the control-treated plants, followed by the plants treated with mild and moderate drought recording $22.6 \%$ and $55 \%$ reductions, respectively. The lowest quantity of starch was recorded in plants grown under severe drought stress conditions showing a reduction of $63.8 \%$ as compared to control-treated plants (Figure 4B). Furthermore, no statistical difference was observed in the free amino acids content of plants grown under mild stress conditions as compared to control-treated plants. However, a significant and linear increase in free amino acids content was recorded in the plants grown under moderate and sever water deficit conditions (Figure $4 \mathrm{C}$ ). The root is the primary organ for water absorption and sensing water deficit. Thus, it plays an important role in plant tolerance to drought stress by regulating water supply to the shoots according to demand and transpiration rates. However, in our study we found that root activity showed a variable response of $C$. pauciflorus to drought stress treatments. Interestingly, the root activity was inhibited by the mild and severe drought stress treatments and promoted by moderate stress conditions. 
A

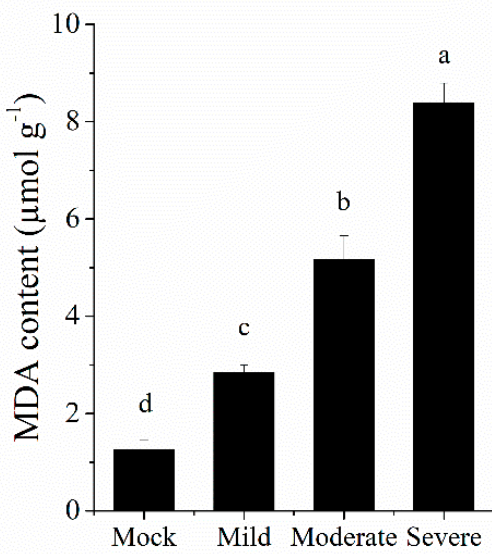

C

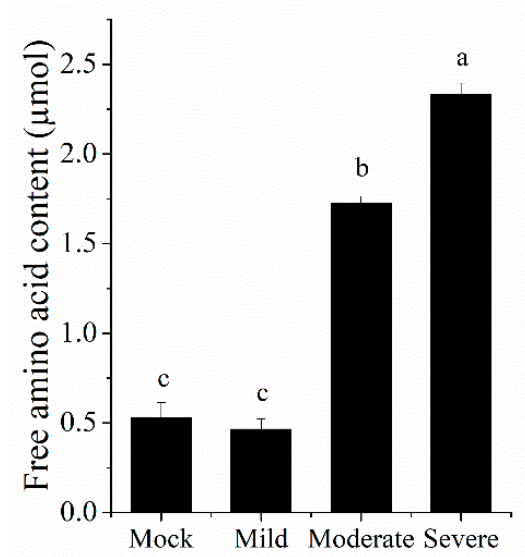

B

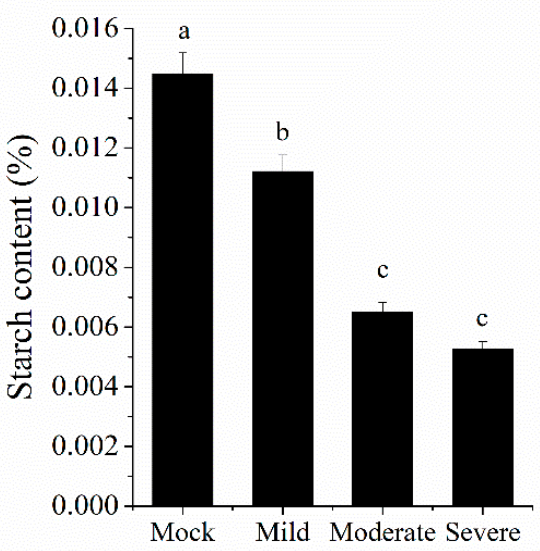

D

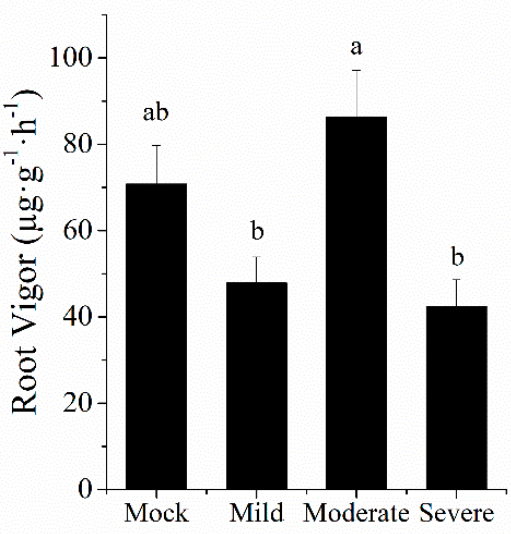

Figure 4. Effect of drought on malondialdehyde (A), starch (B), free amino acids (C), and root vigor (D) of C. pauciflorus. Bars indicate means of at least three replicates. Bars with different letters indicate a significant difference between the two means at $p \leq 0.05$. Error bars indicate standard error (SE). Analysis of variance (ANOVA) was performed at $p \leq 0.05$ and the means with significant differences were separated using Duncan's multiple range test (DMRT).

3.6. Membership Function Analysis (MFA) Based on the 10-Point Index Measured Above to Check the Drought Resistance in C. pauciflorus

A fuzzy membership function analysis approach was used based on the ten drought response indices measured above in order to determine the relative roles of these indices in C. pauciflorus drought responses. The membership function value of each factor was calculated using the equations previously referred to, thereby allowing the more accurate evaluation of drought resistance indicators; the greater the value of MFA, the stronger the drought resistance (Table 3). In the case of mock treatment, the first three indicators capable of the expressing drought resistance of $C$. pauciflorus were starch, root activity and proline content. In the case of mild drought stress treatment, the first three indicators were MDA, CAT activity, and POD activity. On the other hand, in the case of moderate drought stress treatment, the first three strong indicators were CAT activity, soluble protein, and POD activity. Finally, in the case of severe drought stress treatment, the first three indicators were root activity, SOD activity, and MDA. In comparing the treated specimens with the controls, it was found that the root activity and ROS-related enzymes (e.g., SOD, CAT, or POD) of $C$. pauciflorus with high drought resistance were distributed across the range of treatments (Table 3), indicating that C. pauciflorus always uses root activity and the ROS-scavenging system to improve its drought stress response. This phenomenon is not surprising as plant roots are the very place where plants first encounter drought stress 
and thus drought stress always results in the production of reactive oxygen species (ROS), requiring plants to utilize enzymatic or non-enzymatic systems to protect tissues.

Table 3. Analysis of the membership function of drought resistance of Cenchrus pauciflorus Benth.

\begin{tabular}{|c|c|c|c|c|c|}
\hline \multirow{2}{*}{ S. No. } & \multirow{2}{*}{ Indicator } & \multicolumn{4}{|c|}{ Drought Stress Treatment } \\
\hline & & Control & Mild & Moderate & Severe \\
\hline 1 & Superoxide dismutase, SOD & $0.41 \pm 0.01$ & $0.52 \pm 0.03$ & $0.51 \pm 0.07$ & $0.55 \pm 0.03$ \\
\hline 2 & Peroxidase, POD & $0.48 \pm 0.02$ & $0.57 \pm 0.02$ & $0.60 \pm 0.01$ & $0.48 \pm 0.03$ \\
\hline 3 & Catalase, CAT & $0.43 \pm 0.01$ & $0.61 \pm 0.05$ & $0.79 \pm 0.01$ & $0.52 \pm 0.05$ \\
\hline 4 & Root activity & $0.50 \pm 0.04$ & $0.59 \pm 0.04$ & $0.41 \pm 0.01$ & $0.56 \pm 0.01$ \\
\hline 5 & Free amino acid, FAA & $0.45 \pm 0.03$ & $0.49 \pm 0.04$ & $0.51 \pm 0.01$ & $0.51 \pm 0.05$ \\
\hline 6 & Proline, Pro & $0.49 \pm 0.07$ & $0.52 \pm 0.03$ & $0.44 \pm 0.02$ & $0.52 \pm 0.01$ \\
\hline 7 & Malondialdehyde, MDA & $0.47 \pm 0.04$ & $0.61 \pm 0.07$ & $0.52 \pm 0.09$ & $0.53 \pm 0.02$ \\
\hline 8 & Soluble protein, SP & $0.48 \pm 0.01$ & $0.42 \pm 0.03$ & $0.58 \pm 0.01$ & $0.48 \pm 0.03$ \\
\hline 9 & Soluble sugar, SS & $0.46 \pm 0.02$ & $0.46 \pm 0.06$ & $0.45 \pm 0.02$ & $0.46 \pm 0.04$ \\
\hline \multirow[t]{3}{*}{10} & Starch & $0.53 \pm 0.06$ & $0.45 \pm 0.07$ & $0.54 \pm 0.01$ & $0.39 \pm 0.02$ \\
\hline & MFA of Average & $0.47 \pm 0.03$ & $0.52 \pm 0.05$ & $0.54 \pm 0.01$ & $0.50 \pm 0.03$ \\
\hline & Order & 1 & 3 & 4 & 2 \\
\hline
\end{tabular}

\section{Discussion}

The most important factor affecting plant survival in the desert is the amount of available water [32]. In order to get a better picture of the physiological and biochemical responses of plants to drought stress, we chose the invasive plant species C. pauciflorus. This species grows very well in the Horqin sandy area of China which has a dry and hot arid climate and is an area where few plant species can survive. Based on filed observations, the invasive plant $C$. pauciflorus showed a stronger resistance to drought in the Horqin sandy area as compared with other native plants. Therefore, we wanted to investigate the mechanism of physiological and biochemical response of C. pauciflorus to drought stress, aiming to ultimately determine the living strategies used by the plant to grow in sandy land. In this study, the physiological and biochemical responses of C. pauciflorus to drought were investigated. The results indicate that $C$. pauciflorus regulates its cell ROS burst levels by enhancing ROS-scavenged enzymes and non-enzymatic molecules such as proline and MDA. In addition, soluble sugars and soluble proteins in Cenchrus pauciflorus Benth were increased during the drought treatment, contributing to the osmotic maintenance of the cells.

ROS levels increase when plants suffer from adverse conditions, especially drought and salt stress, serving as signaling molecules. However, an increased accumulation of various ROS is also harmful for the cells due to oxidative damage. Plants have evolved anti-oxidative enzymes such as SOD, POX, and CAT to cope with ROS bursts and maintain the cellular oxidative environment at a normal level [33]. It has been shown that drought and salt stress induce the activity of these anti-oxidative enzymes. Consistently, we also found that drought stress enhanced the activity of SOD, POD, and CAT in all treatment of $C$. pauciflorus, especially following the severe drought stress treatment, indicating that this desert plant also uses a similar molecular strategy to cope with ROS bursts caused by drought stress. Our results were consistent with previous research studies which report on drought stress-induced antioxidant enzyme activities [34]. These results suggest that all of these tested three antioxidant enzymes, especially in combination, contribute to the antioxidant capacity of C. pauciflorus, playing important roles in the adaptation of desert plants to drought.

In addition, plant have evolved non-enzymatic systems to cope with elevated ROS during periods of stress, such as proline and MDA. For example, it has been shown that proline levels increase during stress, with proline being widely considered a salt/droughtinducible key metabolic compound that protects cell membranes by decreasing cellular osmotic potential $[35,36]$. It has been recently reported that water deficit induces proline synthesis in shoots, where it acts as a molecular chaperone to sustain the configuration 
of proteins and cell function during stress responses $[37,38]$. The drought sensitive plants always contain lower proline levels as compared to tolerant plants [39]. In the present study, we also found that drought stress increased the production of proline, and this trend was enhanced with the severe drought stress. In addition to proline, MDA has also been reported an important molecular marker of abiotic stress responses [13]. Based on these results, it can be concluded that $C$. pauciflorus shows an increased proline and MDA adaptability to water deficit in desert conditions. The findings of the present study and earlier research reveal that drought stress significantly increases proline and MDA [40]. Furthermore, increased MDA and proline contents are generally accompanied by higher activities of antioxidant enzymes to avoid any oxidative damage caused by drought stress, indicating the important function of proline and MDA for plant tolerance to drought conditions in the desert.

In addition to the antioxidant defense system, osmoregulation is regarded as another important molecular mechanism that aids plant survival and protects cell membrane damage in response to drought environments [41]. Soluble sugars and soluble protein are two important compatible solutes that contribute to the osmotic changeable conditions caused by drought stress in plants [42]. It has been suggested that these two compatible solutes are used by plants to lower their cell's osmotic potential and enable them to sustain positive pressures in drought conditions. These solutes further function as metabolic energy to drive nutriment movement and thus aid in the extraction of water from dry soils [43]. In our study we found a significantly higher accumulation of soluble sugars and soluble protein in the drought-treated plants (Figure 3), which could explain why C. pauciflorus plants show strong resistance to drought in the sandy land. This shows that these are built-in responses of C. pauciflorus, indicating its resilience to drought stress. These measurements have been regularly used by other scientists around the world as a measure of the resistance/susceptibility of plants to drought stress. This result is consistent with other studies reporting that soluble sugars and soluble protein are important in plant resistance to drought. Furthermore, the C. Pauciflorus root cortex and stem have well developed collenchyma cells and vascular bundles (Figure 5A,B). Interestingly, the leaves also show bulliform cell movement that helps the leaves roll over during periods of water shortage (Figure 5C).
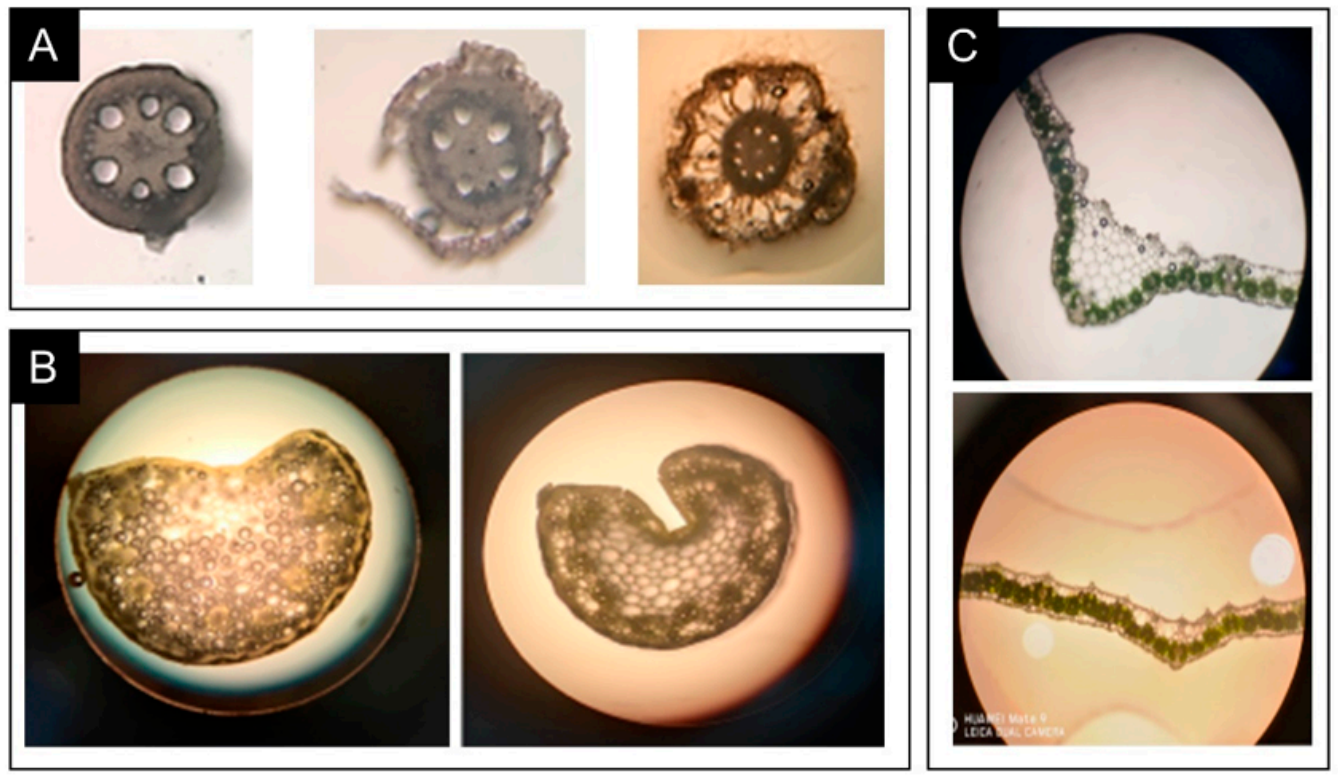

Figure 5. Pauciflorus root cortex and stem have well developed collenchyma cells and vascular bundles (A,B). Furthermore, the leaves show bulliform cell movement that help the leaves roll over during periods of water shortage $(\mathbf{C})$. 
On the basis of the physiological and biochemical analyses, we concluded that C. pauciflorus can survive in sandy conditions through the utilization of an enhanced antioxidant system and osmotic adjustment that protects the plant against oxidative damage under drought conditions.

Author Contributions: L.Z. performed the experiments, X.T. collected and analyzed the data, B.C. and A.H. conceived the idea and wrote the manuscript. All authors have read and agreed to the published version of the manuscript.

Funding: The study was funded by National Natural Science Foundation project of China (31460634) and Innovation and Entrepreneurship fund for students studying abroad in Inner Mongolia.

Institutional Review Board Statement: Not applicable.

Informed Consent Statement: Not applicable.

Data Availability Statement: All data are available in the manuscript.

Conflicts of Interest: The authors declare no conflict of interest.

\section{References}

1. Su, Y.Z.; Zhao, H.L.; Li, Y.L.; Cui, J.Y. Influencing Mechanisms of Several Shrubs on Soil Chemical Properties in Semiarid Horqin Sandy Land, China. Arid Land Res. Manag. 2004, 18, 251-263. [CrossRef]

2. Clavero, M.; García-Berthou, E. Invasive species are a leading cause of animal extinctions. Trends Ecol. Evol. 2005, 20, 110. [CrossRef] [PubMed]

3. Zhang, Z.; Zhang, K.; Tian, X. Characteristics of biological components of Cenchrus pauciflorus under wet and dry habitats. Pratacult. Sci. 2012, 29, 1899-1902.

4. Zhang, Z.; Tian, X.; Bai, Y.; Liu, H.; Niu, X.; Wang, Z.; Wang, Q. Field Sandbur (Cenchrus pauciflorus) Seeds in the Same Bur Respond Differently to Temperature and Water Potential in Relation to Germination in a Semi-Arid Environment, China. PLoS ONE 2016, 11, e0168394. [CrossRef] [PubMed]

5. Erskine-Ogden, J.; Grotkopp, E.; Rejmánek, M. Mediterranean, invasive, woody species grow larger than their less-invasive counterparts under potential global environmental change. Am. J. Bot. 2016, 103, 613-624. [CrossRef]

6. Quattrocchi, U. CRC World Dictionary of Grasses: Common Names, Scientific Names, Eponyms, Synonyms, and Etymology-3 Volume Set; CRC Press: Boca Raton, FL, USA, 2006.

7. Holm, L. The World's Worst Weeds: Distribution and Biology; Lieu de publication non identifié: Krieger publishing Company: Honolulu, HI, USA, 1991.

8. Wu, L.M.; Fang, Y.; Yang, H.N.; Bai, L.Y. Effects of drought-stress on seed germination and growth physiology of quincloracresistant Echinochloa crusgalli. PLoS ONE 2019, 14, e0214480. [CrossRef]

9. Guo, Q.; Wang, Y.; Zhang, H.; Qu, G.; Wang, T.; Sun, Q.; Liang, D. Alleviation of adverse effects of drought stress on wheat seed germination using atmospheric dielectric barrier discharge plasma treatment. Sci. Rep. 2017, 7, 16680. [CrossRef]

10. Wijewardana, C.; Reddy, K.R.; Krutz, L.J.; Gao, W.; Bellaloui, N. Drought stress has transgenerational effects on soybean seed germination and seedling vigor. PLoS ONE 2019, 14, e0214977. [CrossRef]

11. Garg, B.K. Nutrient uptake and management under drought: Nutrient-moisture interaction. Curr. Agric. 2003, 27, 1-8.

12. Pessarakli, M. Handbook of Photosynthesis; CRC Press: Boca Raton, FL, USA, 2016.

13. Fu, J.; Huang, B. Involvement of antioxidants and lipid peroxidation in the adaptation of two cool-season grasses to localized drought stress. Environ. Exp. Bot. 2001, 45, 105-114. [CrossRef]

14. Monakhova, O.F. Cherniad'ev, II, Protective role of kartolin-4 in soil drought in wheat plants. Prikladnaya Biokhimiya i Mikrobiologiya 2002, 38, 433-440.

15. Iqbal, N.; Hussain, S.; Raza, M.A.; Yang, C.-Q.; Safdar, M.E.; Brestic, M.; Aziz, A.; Hayyat, M.S.; Asghar, M.A.; Wang, X.C.; et al. Drought Tolerance of Soybean (Glycine max L. Merr.) by Improved Photosynthetic Characteristics and an Efficient Antioxidant Enzyme Activities Under a Split-Root System. Front. Physiol. 2019, 10, 786. [CrossRef] [PubMed]

16. Huang, B.; Fu, J. Photosynthesis, respiration, and carbon allocation of two cool-season perennial grasses in response to surface soil drying. Plant Soil 2000, 227, 17-26. [CrossRef]

17. Noctor, G.; Reichheld, J.P.; Foyer, C.H. ROS-related redox regulation and signaling in plants. In Seminars in Cell \& Developmental Biology; Academic Press: Cambridge, MA, USA, 2018.

18. Suzuki, N.; Koussevitzky, S.; Mittler, R.; Miller, G. ROS and redox signalling in the response of plants to abiotic stress. Plant Cell Environ. 2012, 35, 259-270. [CrossRef]

19. Kapoor, D.; Bhardwaj, S.; Landi, M.; Sharma, A.; Ramakrishnan, M.; Sharma, A. The Impact of Drought in Plant Metabolism: How to Exploit Tolerance Mechanisms to Increase Crop Production. Appl. Sci. 2020, 10, 5692. [CrossRef] 
20. Jung, T.; Orlikowski, L.; Henricot, B.; Abad-Campos, P.; Aday, A.; Aguín Casal, O.; Bakonyi, J.; Cacciola, S.; Cech, T.; Chavarriaga, D. Widespread Phytophthora infestations in European nurseries put forest, semi-natural and horticultural ecosystems at high risk of Phytophthora diseases. For. Pathol. 2016, 46, 134-163. [CrossRef]

21. Wilkinson, S.; Davies, W.J. Drought, ozone, ABA and ethylene: New insights from cell to plant to community. Plant Cell Environ. 2010, 33, 510-525. [CrossRef]

22. Zhang, H.W.; Zhu, H.F.; Pan, Y.J.; Yu, Y.X.; Luan, S.; Li, L.G. A DTX/MATE-type transporter facilitates abscisic acid efflux and modulates ABA sensitivity and drought tolerance in Arabidopsis. Mol. Plant 2014, 7, 1522-1532. [CrossRef]

23. Zhang, J.H.; Jia, W.S.; Yang, J.C.; Ismail, A.M. Role of ABA in integrating plant responses to drought and salt stresses. Field Crop. Res. 2006, 97, 111-119. [CrossRef]

24. Xueqin, W.; Jin, J.; Jiaqiang, L.; Weimin, Z.; Yibing, Q. Distribution of ephemeral plants and their significance in dune stabilization in Gurbantunggut Desert. J. Geogr. Sci. 2003, 13, 323-330. [CrossRef]

25. Sala, A.; Smith, S.D.; Devitt, D.A. Water Use by Tamarix Ramosissima and Associated Phreatophytes in a Mojave Desert Floodplain. Ecol. Appl. 1996, 6, 888-898. [CrossRef]

26. Cuizhi, F.; Xinyi, W.; Xin, G.; Chunfang, Z.; Haiyan, Z.; Zhizhuang, G.; Weicheng, L.; Jun, C.; Qingsong, Z. Concentration effects and its physiological mechanism of soaking seeds with brassinolide on tomato seed germination under salt stress. ACTA Ecol. Sin. 2021, 41, 1857-1867.

27. Cakmak, I.; Strbac, D.; Marschner, H. Activities of Hydrogen Peroxide-Scavenging Enzymes in Germinating Wheat Seeds. J. Exp. Bot. 1993, 44, 127-132. [CrossRef]

28. Baghizadeh, A.; Salarizadeh, M.; Abaasi, F.J.I.J.A.S. Effects of Salicylic acid on some physiological and biochemical parameters of Brassica napus L.(Canola) under salt stress. Int. J. Agric. Sci. 2014, 4, 147-152.

29. Aragão, V.P.M.; Navarro, B.V.; Passamani, L.Z.; Macedo, A.F.; Floh, E.I.S.; Silveira, V.; Santa-Catarina, C. Free amino acids, polyamines, soluble sugars and proteins during seed germination and early seedling growth of Cedrela fissilis Vellozo (Meliaceae), an endangered hardwood species from the Atlantic Forest in Brazil. Theor. Exp. Plant Physiol. 2015, 27, 157-169. [CrossRef]

30. Chow, P.S.; Landhausser, S.M. A method for routine measurements of total sugar and starch content in woody plant tissues. Tree Physiol. 2004, 24, 1129-1136. [CrossRef]

31. Liu, J.J.; Wei, Z.; Li, J.H. Effects of copper on leaf membrane structure and root activity of maize seedling. Bot. Stud. 2014, 55, 47. [CrossRef]

32. Davey, M.W.; Stals, E.; Panis, B.; Keulemans, J.; Swennen, R.L. High-throughput determination of malondialdehyde in plant tissues. Anal. Biochem. 2005, 347, 201-207. [CrossRef]

33. Mittler, R. Oxidative stress, antioxidants and stress tolerance. Trends Plant Sci. 2002, 7, 405-410. [CrossRef]

34. Bian, S.; Jiang, Y. Reactive oxygen species, antioxidant enzyme activities and gene expression patterns in leaves and roots of Kentucky bluegrass in response to drought stress and recovery. Sci. Hortic. 2009, 120, 264-270. [CrossRef]

35. Handa, S.; Handa, A.K.; Hasegawa, P.M.; Bressan, R.A. Proline accumulation and the adaptation of cultured plant cells to water stress. Plant Physiol. 1986, 80, 938-945. [CrossRef]

36. Petrov, P.; Petrova, A.; Dimitrov, I.; Tashev, T.; Olsovska, K.; Brestic, M.; Misheva, S. Relationships between leaf morpho-anatomy, water status and cell membrane stability in leaves of wheat seedlings subjected to severe soil drought. J. Agron. Crop Sci. 2018, 204, 219-227. [CrossRef]

37. Sharma, S.; Villamor, J.G.; Verslues, P.E. Essential role of tissue-specific proline synthesis and catabolism in growth and redox balance at low water potential. Plant Physiol. 2011, 157, 292-304. [CrossRef] [PubMed]

38. Verbruggen, N.; Hermans, C. Proline accumulation in plants: A review. Amino Acids 2008, 35, 753-759. [CrossRef] [PubMed]

39. Liu, S.; Wang, C.; Jia, F.; An, Y.; Liu, C.; Xia, X.; Yin, W. Secretory peptide PdEPF2 enhances drought tolerance by modulating stomatal density and regulates ABA response in transgenic Arabidopsis thaliana. Plant Cell Tissue Organ Cult. 2016, 125, 419-431. [CrossRef]

40. Moussa, H.R.; Abdel-Aziz, S.M. Comparative response of drought tolerant and drought sensitive maize genotypes to water stress. Aust. J. Crop Sci. 2008, 1, 31-36.

41. Morgan, J.; Morgan, K. Alteration of cytoplasmic ionized calcium levels in smooth muscle by vasodilators in the ferret. J. Physiol. 1984, 357, 539-551. [CrossRef]

42. Chaves, M.M.; Maroco, J.P.; Pereira, J.S. Understanding plant responses to drought-From genes to the whole plant. Funct. Plant Biol. 2003, 30, 239-264. [CrossRef]

43. Holbrook, N.M.; Zwieniecki, M.A. Embolism repair and xylem tension: Do we need a miracle? Plant Physiol. 1999, 120, 7-10. [CrossRef] 